\title{
George A. Savoy, Visionary Benefactor of Canadians with Epilepsy, and the History of the Savoy Foundation for Epilepsy
}

\author{
C.M. Rémillard, B.G. Zifkin, A. Sherwin and W. Feindel
}

\begin{abstract}
George A. Savoy was born in Cohoes, New York, in 1873. He left the U.S.A. in 1921 to manage the Canadian branch of a large manufacturer of ledgers and looseleaf registers. This company was asked to supply Professor Jasper's laboratory with rolls of plain unlined paper and it was George Savoy who later developed fanfolded and lined EEG paper, which was first used at the Montreal Neurological Institute. He also had personal contacts with Wilder Penfield concerning their mutual interest in the needs of patients with epilepsy. He was a successful industrialist involved with several charitable organizations funding programmes for people with epilepsy. He was opposed to the sectarianism then prevalent in Quebec, which was unfamiliar to him, and in reaction built his own institution, Dieppe House, a home for people with epilepsy, later renamed «Foyer Savoy». It was to operate without regard to race, language or religion. In 1971, his son Harold and other generous donors decided to create a foundation to support research in epilepsy. The Foyer Savoy was sold in 1988 and the proceeds used to increase the endowment of the foundation. His grandson George M. Savoy is the current president. The fourth generation is also represented by Caroline Savoy, daughter of the president, who joined the board of directors in 1992. The foundation will distribute from $\$ 300,000$ to $\$ 400,000$ yearly to researchers from many different countries working in the field of epilepsy in universities and hospitals throughout Canada.
\end{abstract}

RÉSUMÉ: George A. Savoy, un bienfaiteur visionnaire des épileptiques canadiens, et l'histoire de la Fondation Savoy pour l'épilepsie. George A. Savoy est né à Cohoes, New York, en 1873. Il quitta les États-Unis en 1921 pour administrer la filiale canadienne d'un important manufacturier de registres et de cartables à feuilles mobiles. On demanda à cette compagnie de foumir des rouleaux de papier non ligné au laboratoire du professeur Jasper et c'est George Savoy qui eventuellement développa le papier à EEG plié en éventail et ligné, qui fut utilisé d'abord à l'Institut Neurologique de Montréal. Il eut aussi des contacts personnels avec Wilder Penfield concernant leur intérêt commun pour les besoins des patients épileptiques. George Savoy fut un industriel prospère, qui s'impliqua dans plusieurs organisations charitables finançant des programmes pour les épileptiques. Il était opposé au sectarisme alors prévalent au Québec, avec lequel il n'était pas familier, et il construisit sa propre institution, la Maison Dieppe, un foyer pour épileptiques plus tard renommé "Foyer Savoy". Ce foyer recevait des patients sans égard à leur race, à leur langue ou à leur religion. En 1971, son fils Harold et d'autres généreux donateurs on décidé de créer une fondation pour subventionner la recherche sur l'épilepsie. Le Foyer Savoy fut vendu en 1988 et le produit de la vente fut utilisé pour accroître le capital de la fondation. Son petit-fils, George M. Savoy en est le président actuel. La quatrième génération est représentée par Caroline Savoy, la fille du président, qui s'est jointe au conseil d'administration en 1992. La fondation distribuera entre $\$ 300,000$ et $\$ 400,000$ annuellement à des chercheurs de plusieurs pays qui travaillent dans le domaine de l'épilepsie dans des universités et des hopitaux à travers le Canada.

Can. J. Neurol. Sci. 1996; 23: 80-82

George A. Savoy was born in Cohoes, New York, USA in 1873 and left Holyoke, Massachussets in 1921 to manage Canadian operations of the Dominion Blankbook Company Ltd, an important manufacturer of ledgers and business stationery. They located first in Berthier, Québec and later moved to StJean-sur-Richelieu where they are to this day. Around this time, Mme Lucie Bruneau was vice-president of a subcommittee of the St-Jean-Baptiste Society mandated to visit hospitals. She was also the founding president of «L'Aide aux infirmes», which in 1926 opened a school «for the handicapped and epileptic» on the grounds of Ste-Justine's Hospital for Children in 1926. George A. Savoy found time from his business to be active in two organizations which supported Lucie Bruneau's

From the Département des Sciences Neurologiques, Hopital du Sacré-Cocur de Montréal, Université de Montréal (G.M.R., B.G.Z.); and the Department of Neurology and Neurosurgery, Montreal Neurological Institute, McGill University (A.S., W.F.) RECEIVED MAY 30. 1995. ACCEPTED IN FINAL, FORM SEPTEMBER 28, 1995.

Reprint requests to: Docteur Guy Rémillard, 10720, rue Tanguay, Montréal, Québec, Canada $\mathrm{H} 3 \mathrm{~L} 3 \mathrm{H} 2$ 
Aide aux infirmes, «La Fédération des oeuvres de charité canadiennes françaises» and the Saint-Laurent Kiwanis Club.

In 1933, Lucie Bruneau founded the «Établissements NotreDame», a branch of L'Aide aux infirmes, for epileptic patients of both sexes. A permanent home was sought for it, preferably near Montréal, where she could establish a school and agricultural institute and later a sheltered workshop and residence. After discussions at the office of L'Aide aux infirmes, in October 1942, the organization bought l'Ile aux Cerfs, an island located in the Richelieu river at St-Charles. Medical opinion at the time held that this location would be ideal for the treatment of epilepsy. It was peaceful, secure and in the open air. Its isolation was conducive to study and manual labour. Suitable training for women with epilepsy was to consist of needlework, weaving, knitting, cooking, the production of rosaries and the cultivation of small fruits and flowers. Boys and men were to learn farm work, animal husbandry, bookeeping, market gardening, shoemaking, carpentry, bookbinding, drawing and engraving, etc.

Lucie Bruneau convinced the St-Laurent Kiwanis Club to mount a campaign to finance the construction of a hospital for epileptic patients on the Ile aux Cerfs, with George A. Savoy, an active member of the club, placed in charge. He was surprised to learn that admission to this institution was to be restricted to French-Canadian Catholics with epilepsy. He was adamantly opposed to this blatant sectarianism which was unfamiliar to him. He threatened to build his own institution which would operate without regard to race, language or religion.

Meanwhile, on October 22, 1942, a meeting was held at the archbishop's residence in Montréal. Monsignor Chaumont, auxiliary bishop of Montréal, brought together Alfred Bernier of l'Association Professionnelle Catholique des voyageurs de commerce; Joseph Dansereau of La Commission des Écoles Catholiques de Montréal; Philippe Girard of Le Syndicat Catholique; Joseph Hébert, president of Les Ligues du SacréCoeur; the Honorable Judge Arthur Laramée, president of L'Oeuvre des retraitants; Dr J.A. Samson, orthopaedic surgeon at l'Hôpital du Sacré-Coeur de Montréal; Donat Turcotte, vice-president of La Société de Secours aux enfants catholiques romains; and Guy Vanier of La Société St-Jean-Baptiste. Charles E. Geoffrion of La Fédération des Oeuvres de charité canadiennes françaises and G.E. Julien, president of La Société St-Vincent-dePaul were invited but could not attend. This assembly was to discuss forming an advisory council to L'Aide aux Infirmes represented that night by Lucie Bruneau and which would then be known as L'Association Catholique de l'aide aux infirmes. Mgr Chaumont explained why he had decided to take the welfare of this essentially Catholic organization in hand personally. Two years before, La Société de Secours had persuaded Catholic families of disabled children to send them not to the summer camp of L'Aide aux infirmes, but to a different camp at Joliette. Here both boys and girls of all religions were admitted, with ministers of different denominations conducting services for them. The policy of the Church, Chaumont pointed out, was clearly against mixed marriages. One could easily imagine, he noted, the serious danger to Catholic youth who, seeing different religions treated equally, might conclude that all religions are equally good.

At a special financial campaign meeting at the home of Mme Lucie Bruneau on February 26, 1943, also attended by George
Savoy on behalf of the Kiwanis Club, it was decided that Les Établissements Notre-Dame was for the benefit of all educable epileptic residents of Québec without regard to their origin, and that support from both anglophone and francophone donors was to be solicited. No gift, however, could include conditions that could contravene the charter of the governing foundation of Les Établissements Notre-Dame. There was also to be no religious discrimination in admissions but the institution was to be officially Catholic and managed by nuns.

In a letter to Lucie Bruneau dated March 30, 1943, George Savoy noted that he had promised business colleagues and friends that in exchange for their generous contributions, he would make certain demands as to the management of the institution. In a letter of May 12, 1943, he asked for their money to be returned to them, saying that Lucie Bruneau had given her word that the institution would be managed by experienced businessmen and professionnals, but that she had now refused this request. He gave notice that he would attend no further meetings and that he would work apart.

At the end of the campaign, the new institution, on l'lle aux Cerfs, received a cheque for $\$ 30,763.36$. A third of this had been raised by George Savoy and was returned to him. The list of subscribers showed at its head, on December 4, 1942, George A. Savoy, $\$ 500$ in memory of his son Major Paul R. Savoy, killed in the landing at Dieppe; the second December 24, 1942, Provincial Bank of Canada \$250; the third January 5, 1943, $\mathrm{Mr}$ Prew Savoy of the Quincy Trust Company at Washington \$500; and others for a total of $\$ 10,000$. On June 5, 1944, George A. Savoy wrote to Lucie Bruneau, president of Les Établissements Notre-Dame, requesting an appointment to discuss closer relations. He noted «...we are no more in competition than are Notre-Dame Hospital, the Hôtel-Dieu, and the Royal Victoria Hospital...». The Montreal Star of June 27, 1944, reported: "New Home for Epileptics now assured for province; leading citizens make possible comfort and training for sick». These plans were based on those of the Rockefeller Foundation. On the recommendation of the Minister of Health, the Honorable Henri

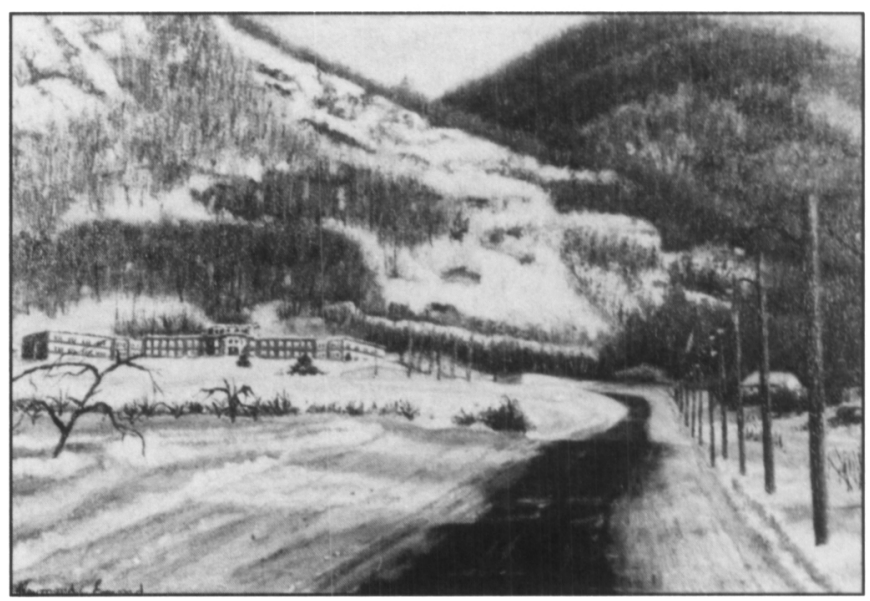

Figure 1: Dieppe House, a home for epileptics later renamed Fover Savoy, built on a farm situated on Mont St-Hilaire located in the towin of Saint-Hilaire, Québec. (Painting by Raymonde Emond, 1987) 
Groulx, the provincial government granted $\$ 240,000$ to Savoy's organization and $\$ 160,000$ to Les Établissements Notre-Dame directed and managed by the women of L'Association Catholique de l'Aide aux infirmes. Albert Plante, s.j., wrote: «This new nonsectarian scheme, still only a project based on our plans, our experience, and our programmes, has obtained the sum of $\$ 240,000$ upon its first request to the provincial government, while Les Établissements Notre-Dame, a private initiative founded in 1933 after many difficulties and functioning with 70 students, has received after repeated requests in the name of the French-speaking Catholic population of this province, a grant which is one-third smaller». Two years later, on November 12, 1946, the Montreal Star reported the opening of the modern and nonsectarian Dieppe House (Figure 1) by Chief Justice Sévigny. George A. Savoy had named it in memory of his son, killed in the disastrous raid on Dieppe. As he had previously stated, George A. Savoy had worked apart after the split of 1942 and built his own institution. Les Établissements Notre-Dame had developed their own centre in 1942 on L'Ile aux Cerfs, headed by Lucie Bruneau, which was sold to the Catholic Church in 1946. Its students were later transferred to an institute for epileptic youth opened by Monsignor Chaumont.

During the $50^{\text {th }}$ anniversary celebrations of the Eastern Association of Electroencephalographers in 1989, Dr Herbert Jasper recalled:

"When we arrived from the United States, we had to build our own apparatus and there was no one in Canada supplying the recording paper needed for EEG records. At the time, George Savoy supplied us with rolls of plain unlined paper which was rather awkward to use. He then developed the fan-folded and lined paper which is still standard for EEG records. He was very helpful in showing much interest in the development of our laboratories and in the promotion of research and treatment of epileptic patients at the Institute as well as in the organization of EEG conferences held in the Laurentian mountains during the winter. The EEG ski meeting soon became very popular and attracted the leading epileptologists throughout North America and many from Europe as well.»

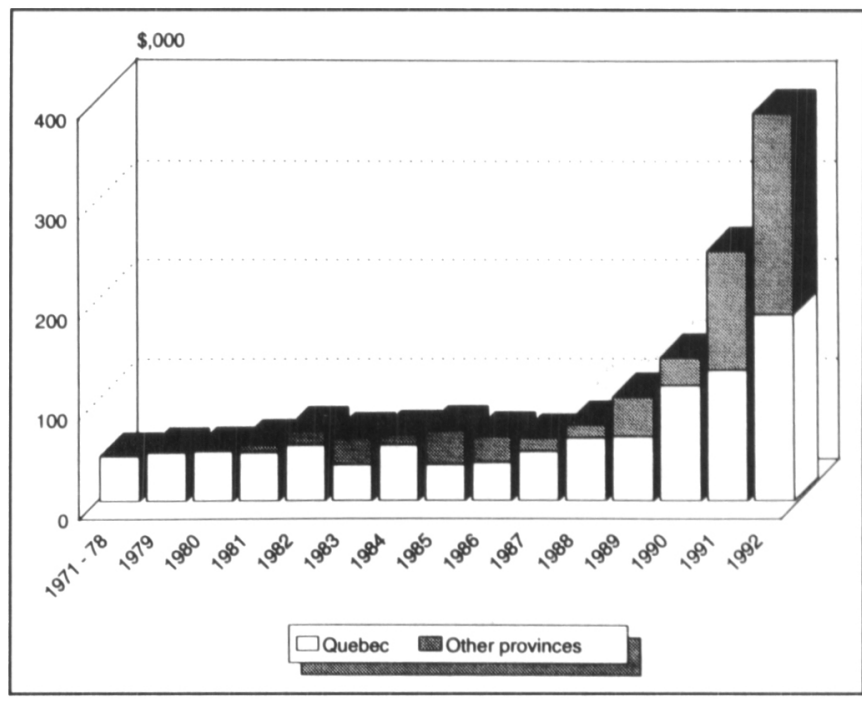

Figure 2: Amounts distributed to researchers from all countries in the field of epilepsy in Canadian hospitals and universities until 1992, the fiftieth anniversary of the Foundation. They have kept growing over the years, especially after 1988 when the Foyer and the adjacent farmland on Mont Saint-Hilaire were sold and the proceeds used to endow the Foundation.

George A. Savoy also donated the Savoy silver cup to the organization, presented to the winner of the downhill ski race at these gatherings. Dr William Feindel was the first winner in 1950.

In 1969, Dieppe House became the Foyer Savoy and government restructuring of health care and social services led to a change in mission. The descendants of George Savoy and other generous donors decided to create a foundation to support research in epilepsy. This was done in 1971. The Foyer and the adjacent farmland situated on Mont St-Hilaire was sold in 1988 and the proceeds used to endow the foundation. About $\$ 300,000$ to $\$ 400,000$ will be distributed yearly to researchers in the field of epilepsy from all countries working in universities and hospitals throughout Canada and also to Canadian scientists studying abroad (Figure 2).

\section{ACKNOWLEDGEMENT}

We are grateful to L'Institut de Réadaptation Lucie Bruneau for access to the archives and correspondence of L'Aide aux infirmes. 